Vol. 1 No. 3 Juli 2021 e-ISSN : 2774-6283 | p-ISSN : 2775-0019

\title{
PENGGUNAAN PROBLEM BASED LEARNING UNTUK MENINGKATKAN READING SKILL SISWA XI OTKP 2 SMK NEGERI 2 BLITAR TAHUN 2019-2020
}

\author{
SITI JUWARIYAH SHOBARIYATI \\ SMK Negeri 2 Blitar \\ e-mail: ctjuwariyah76@gmail.com
}

\begin{abstract}
ABSTRAK
Penelitian dalam penerapan Problem Based Learning ini dilakukan untuk mengetahui terjadinya peningkatan Reading Skill terkait Passive Voice siswa XI OTKP 2 SMK Negeri 2 Blitar. Penelitian ini terdiri atas dua siklus yang setiap siklus terdiri atas empat tahapan. Masing-masing siklus dilaksanakan dalam dua kali tatap muka. Pada awalnya, kemampuan siswa dalam menggunakan Passive Voice masih rendah. Hanya delapan siswa tuntas pada ranah kognitif, 16 siswa pada ranah afektif, dan 12 siswa pada ranah psikomotorik. Setelah dilakukan penelitian, maka hasil analisis menunjukkan bahwa Reading Skill siswa terkait Passive Voice mengalami peningkatan yang cukup signifikan. Sebanyak 30 siswa bisa menuntaskan pembelajaran pada ranah kognitif, 36 siswa pada ranah afektif, dan 30 siswa pada ranah psikomotorik. Secara otomatis persentase ketuntasan klasikal juga mengalami peningkatan dari 33\% menjadi 89\%. Dengan demikian, Problem Based Learning berhasil diterapkan pada siswa XI OTKP 2 SMK Negeri 2 Blitar semester genap tahun akademik 2019-2020.
\end{abstract}

Kata kunci: Problem Based Learning, Reading Skill, Passive Voice

\section{PENDAHULUAN}

Semua bahasa mempunyai empat keterampilan yang harus dimiliki penuturnya. Empat keterampilan tersebut adalah keterampilan menyimak, berbicara, membaca, dan menulis. Demikian juga dengan Bahasa Inggris yang juga mepunyai empat keterampilan itu. Penutur Bahasa Inggris menyebutnya dengan Listening, Speaking, Reading, dan Writing Skill. Semua keterampilan itu harus dikuasai dengan baik sehingga bisa dimanfaatkan untuk berkomunikasi dengan baik dan benar.

Banyak alasan yang menjadi penyebab mengapa Bahasa Inggris sering menjadi momok bagi sebagian besar siswa. Salah satunya adalah bahwa di sekolah biasanya mereka hanya menggunakan buku teks sebagai media untuk belajar. Tomlinson (2008:3) mengatakan bahwa buku teks menjadi salah satu penyumbang besar kegagalan siswa dalam mempelajari Bahasa Inggris sebagai bahasa kedua atau juga bahasa asing, sehingga pada akhir masa belajarnya mereka tidak mampu menggunakannya untuk berkomunikasi dengan benar.

Passive Voice termasuk materi pelajaran Bahasa Inggris yang sulit difahami oleh siswa (Ruzhekova-Rogozherova: 2012). Begitu juga bagi pengajar, mengajarkan materi ini tergolong yang tersulit karena konstruksinya. Namun demikian, penggunaan Pasive Voice sangat sering ditemukan dalam komunikasi riil. Oleh karena itu materi ini harus benar-benar dikuasai siswa dengan baik. Ketika menemui sebuah teks -lisan maupun tulis- siswa harus mampu memaknai setiap kalimat sesuai konteksnya. Begitu juga dengan fungsi sosial dan unsur kebahasaannya.

Problem Based Learning merupakan salah satu model pembelajaran yang digunakan dalam Kurikulum 2013. Dalam model ini, masalah autentik digunakan sebagai pemicu proses belajar siswa sebelum mereka mengetahui konsep formal tertentu (Fathurrohman, 2015:112). Selanjutnya dijelaskan bahwa mereka mencari beberapa informasi dan strategi yang relevan, mengidentifikasinya secara kritis, dan kemudian melakukan investigasi untuk memecahkan masalah. Siswa bekerjasama dengan kelompok mereka untuk memecahkan masalah yang diberikan. Dalam hal ini adalah siswa diberikan sebuah teks bacaan yang harus mereka baca dan selesaikan permasalah-permasalahan yang diberikan. Mereka benar-benar belajar mengumpulkan informasi yang tepat dan melakukan percobaan untuk mendapatkan klarifikasi untuk memecahkan masalah tersebut. Hasil diskusi kelompok didiskusikan bersama untuk 
kemudian dilakukan refleksi dan evaluasi dalam proses pemecahan masalah yang mereka lakukan.

Penggunaan Problem Based Learning dalam proses pembelajaran di kelas diharapkan mampu melatih kompetensi siswa dalam menyelesaikan masalah riil yang mereka temui dalam kehidupan sehari-hari, dalam hal ini masalah dalam beberapa teks yang berisi kalimat-kalimat pasif. Melihat hasil belajar dan keterampilan siswa dalam menggunakan Passive Voice -baik dalam teks tertulis maupun lisan-.tahun demi tahun selalu rendah, maka fenomena ini melatarbelakangi perlunya diadakan suatu penelitian untuk memperbaiki pemahaman dan keterampilan siswa dalam menggunakannya. Hal ini juga terjadi pada proses pembelajaran di kelas XI OTKP 2, SMK Negeri 2 Blitar, tahun 2019 yang juga terlihat bahwa kemampuan mereka dalam memahami teks bacaan tertulis yang didalamnya terdapat Pasive Voice sangat kurang.

Selanjutnya berdasarkan latar belakang yang diuraikan, rumusan masalah yang diajukan dalam penelitian ini adalah bagaimana penerapan Problem Based Learning dalam pembelajaran Passive Voice di kelas XI OTKP 2 sehingga dapat meningkatkan hasil belajar dan Reading Skill mereka. sedangkan tujuan penelitiannya adalah mendeskripsikan bagaimana penerapan Problem Based Learning dalam pembelajaran di kelas sehingga dapat meningkatkan hasil belajar dan Reading Skill siswa XI OTKP 2 tahun pelajaran 2019-2020.

\section{METODE PENELITIAN}

Penelitian yang telah dilakukan dirancang sebagai Penelitian Tindakan Kelas (PTK). Subyek penelitian adalah siswa XI OTKP 2 SMK Negeri 2 Blitar. Jumlah siswa adalah 36 orang. Penelitian terdiri dari dua siklus yang setiap siklus dilakukan dalam dua kali pertemuan. Pada masing-masing siklus dilakukan empat tahap yaitu perencanaan, tindakan, observasi, dan refleksi.

Berikut ini adalah gambar rancangan penelitian tindakan kelas menurut Arikunto, Suhardjono, dan Supardi (2002).

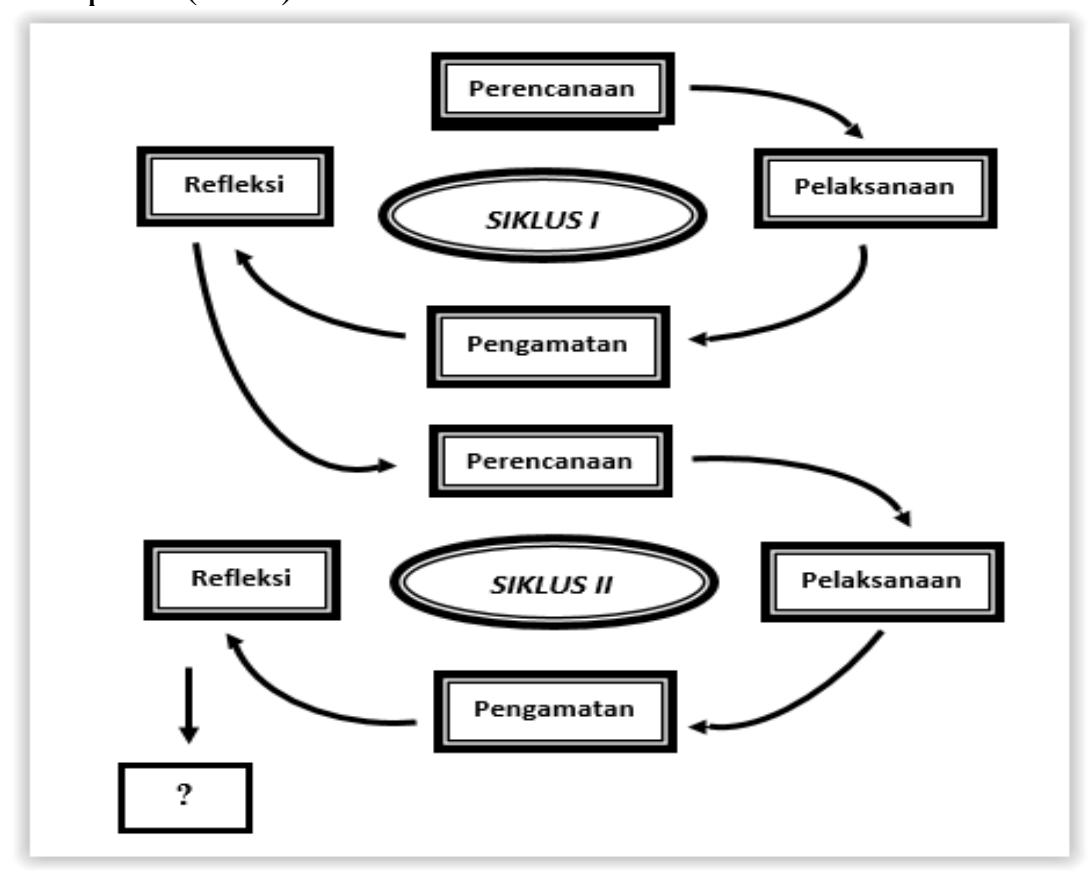

\section{Gambar 1. Rancangan Penelitian Tindakan Kelas}

Sesuai dengan rancangan yang telah ditetapkan, pada siklus I telah dilaksanan empat tahapan yaitu (1) perencanaan, (2) pelaksanaan, (3) pengamatan, dan (4) observasi. Pada tahap perencanaan, kegiatan yang telah dilakukan oleh peneliti adalah melakukan observasi awal dan merumuskan desain penelitian yang meliputi: menentukan tujuan pembelajaran, mendesain skenario pembelajaran menggunakan Model Problem Based Learning, menyiapkan media 
pembelajaran, menyusun lembar observasi, membuat quiz untuk pre-test dan post-test, menyiapkan work sheet untuk didiskusikan, dan berkoordinasi dengan pengamat yang merupakan teman sejawat peneliti. Selanjutnya dilanjutkan dengan tahap pelaksanaan. Pada tahap ini, peneliti berperan sebagai guru yang melaksanakan kegiatan pembelajaran di dalam kelas yang diteliti. Penerapan kegiatan pembelajarannya sesuai dengan Rencana Pelaksanaan Pembelajaran (RPP) yang telah dibuat sebelumnya. Tahap selanjutnya adalah observasi yang dilakukan bersamaan dengan proses pembelajaran berlangsung. Objek yang diamati adalah aktivitas guru sebagai pemberi tindakan dan aktivitas siswa selama proses pembelajaran. Hasil observasi dicatat dalam lembar observasi dan catatan. Yang terakhir adalah tahap ke-empat yaitu refleksi. Pada tahap ini, kegiatan yang dilakukan adalah mengolah dan menganalisisis data yang diperoleh pada saat pelaksanaan tiap tahap. Hasilnya adalah skor siswa terkait dengan tindakan yang diberikan. Hasil dari tahap terakhir ini dikaji ulang untuk kemudian dilanjutkan pada Siklus II dengan harapan setelahnya permasalahan dapat teratasi.

Pelaksanaan Siklus II diawali dengan perencanaan. Pada tahap ini peneliti sebagai guru bahasa Inggris bersama dengan observer mempertimbangkan hasil refleksi dari tindakan pada Siklus I. Hasilnya menjadi pertimbangan yang efektif yang dilaksanaan pada Siklus II. Pada tahap pelaksaan, tindakan yang dilakukan sama dengan tahap siklus I dengan memperhatikan penyesuaian dan perbaikan yang dibuat berdasarkan hasil refleksi pada siklus I. Rencana Pelaksanaan Pembelajaran (RPP) juga diperbaiki untuk siklus II ini. Tahap selanjutnya adalah pengamatan. Sama dengan di Siklus I, tahap ini dilaksanakan bersamaan dengan pelaksanaan tindakan pembelajaran di kelas. Hal yang menjadi fokus pengamatan pun sama dengan yang diamati pada siklus I. Dari tahap ini diperoleh gambaran bagaimana pengaruh penerapan tindakan yang telah dirumuskan oleh peneliti. Hasil pada siklus II merupakan refleksi akhir dari penelitian. penelitian.

Berikut ini adalah instrument dan teknik pengumpulan data yang dipakai dalam

Tabel 1. Instrumen dan Teknik Pengumpulan Data

\begin{tabular}{|c|c|c|c|}
\hline No. & Data & Instrumen & Teknik \\
\hline 1. & Hasil belajar siswa & - Tes & - pre-test dan post-test \\
\hline 2. & Respon siswa & - kuisioner & - pengisian kuisioner oleh siswa \\
\hline 3. & $\begin{array}{l}\text { Proses } \\
\text { pembelajaran } \\
\text { sebelum dan } \\
\text { sesudah Problem } \\
\text { Based Learning }\end{array}$ & $\begin{array}{l}\text { - } \text { interview } \\
\text { - catatan } \\
\text { lapangan } \\
\text { - observasi }\end{array}$ & $\begin{array}{l}\text { - meng-interview pengamat } \\
\text { - menulis catatan lapangan selama } \\
\text { proses pembelajaran } \\
\text { - observasi langsung dan mencatat } \\
\text { semua aktivitas selama proses } \\
\text { pembelajaran }\end{array}$ \\
\hline
\end{tabular}

\section{HASIL DAN PEMBAHASAN}

\section{A. Hasil Penelitian}

\section{Siklus I}

Pelaksanaan penelitian diawali dengan perencanaan. Tahap ini dilakukan oleh guru/peneliti sebagai peneliti sebelum pertemuan tatap muka di kelas. Kegiatan yang dilakukan adalah mengeksplorasi materi (teks bacaan dalam Passive Voice) dengan melakukan kegiatan sebagai berikut: menganalisis kurikulum penggunaan Passive Voice dalam bacaan yang akan diajarkan, menggali beberapa teori tentang Pendekatan Ilmiah dan Model Problem Based Learning, membuat Rencana Pelaksanaan Pembelajaran (RPP), menyusun work sheet, menyusun instrumen Penelitian Tindakan Kelas, dan menyusun alat evaluasi untuk mengukur kemampuan peserta didik.

Tahap selanjutnya adalah pelaksanaan tindakan proses belajar mengajar di dalam kelas. Pembelajaran dilaksanakan dengan menggunakan model yang telah dirancang di RPP. Setelah 
mengkondisikan kelas, peneliti menyampaikan tujuan pembelajaran dan cakupan materi yang dipelajari. Selanjutnya siswa mengerjakan pre-test.

Pada inti pembelajaran, siswa diberi sebuah teks pendek untuk dibaca dan diamati. Beberapa masalah terkait materi ajar dan kegunaannya dalam kehidupan mereka ditanyakan siswa selama kurang lebih 15 menit. Guru/peneliti memfasilitasi mereka untuk jawabannya. Setelahnya, mereka dibagi ke dalam enam kelompok untuk mendiskusikan masalah-masalah diberikan oleh guru/peneliti. Data mereka kumpulkan dari berbagai macam sumber untuk mereka diskusikan sebagai bahan untuk memecahkan masalahnya.

Pada akhir pertemuan pertama siswa dan guru/peneliti membuat kesimpulan atas pembelajaran yang telah dilakukan. Terakhir yang dilakukan guru/peneliti dan siswa adalah mengevaluasi, merefleksi, dan memberikan umpan balik terhadap kegiatan pembelajaran yang telah dilaksanakan.

Pertemuan kedua dilaksanakan satu minggu kemudian. Pada kegiatan pendahuluan dilakukan review tentang kegiatan yang telah dilaksanakan dan dikerjakan siswa pada pertemuan pertama. Kegiatan pada pertemuan kedua adalah melanjutkan mendiskusikan dan menyelesaikan permasalahan yang diberikan pada pertemuan sebelumnya. Siswa mendiskusikannya dengan kelompok kecil mereka sekitar 15 menit. Selanjutnya enam kelompok kecil dipertemukan dalam diskusi kelas dengan pantauan guru/peneliti dan observer.

Di akhir pertemuan kedua diadakan post-test untuk mengukur pemahaman siswa terhadap materi yang telah dipelajari sebelumnya. Hasil pengamatan dan tes selama proses pembelajaran Siklus I dapat dilihat pada grafik di bawah ini untuk kognitif, afektif, dan psikomotor.

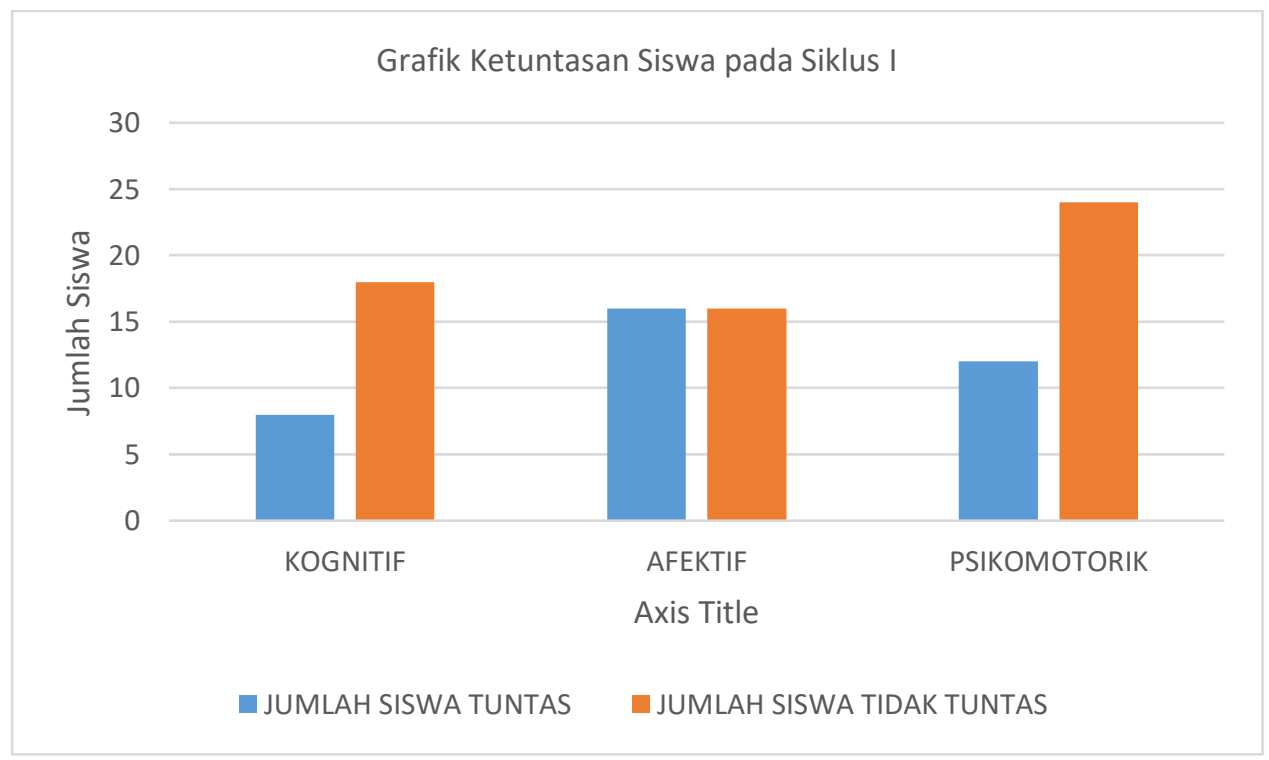

Gambar 2. Hasil Pengamatan Siklus 1

Dari grafik di atas, diketahui bahwa hasil belajar Passive Voice siswa XI OTKP 2 masih rendah. Dari 36 siswa hanya 8 siswa yang tuntas untuk ranah kognitif, 16 siswa untuk afektif, dan 12 siswa untuk psikomotorik. Karena yang berhasil menuntaskannya belum mencapai 85\% dari jumlah siswa, maka kesimpulan yang bisa diambil adalah bahwa ketuntasan klasikal kelas XI OTKP 2 belum tercapai. Sebagaimana dinyatakan bahwa jika sejumlah $85 \%$ siswa dalam suatu kelas sudah menuntaskan belajarnya, maka ketuntasan klasikalpun tercapai (Trianto dalam Fauzan, 2019).

Keberhasilan guru/peneliti dalam menerapkan Problem Based Learning juga masih kurang. Terbukti bahwa guru/peneliti hanya memperoleh skor 23 dari total 51 sebagaimana telah diamati oleh observer. Ini berarti tingkat keberhasilan penerapan Problem Based Learning, hanya $45 \%$ saja. 
Hasil refleksi siklus I menunjukkan bahwa penyebab ketidaktuntasan belajar siswa bukan hanya berasal dar siswa, tetapi guru/peneliti pun ikut adil di dalamnya. Beberapa faktor penyebab dari siswa antara lain: (1) hanya siswa tertentu yang aktif yang betul-betul serius mengikuti pembelajaran, sedangkan siswa-siswa yang lain hanya sekedar mengikuti arus saja tanpa berperan yang maksimal (2) siswa dengan kemampuan biasa tertinggal dari temannya yang memiliki kemampuan lebih baik, (3) pembagian kelompok yang kurang merata antara siswa yang berkemampuan lebih dan kurang. Sedangkan faktor penyebab dari guru antara lain sebagai berikut: (1) guru/peneliti tidak menjelaskan tahapan-tahapan dalam pembelajaran model Problem Based Learning sehingga siswa tidak terarah dengan baik pada saat proses pembelajaran, (2) guru/peneliti menyerahkan sepenuhnya pembagian kelompok kepada siswa sehingga terdapat ketimpagan yang menyolok antara kelompok siswa yang aktif dan kurang aktif, (3) guru/peneliti kurang menguasai kelas karena lebih sering merespon kelompokkelompok yang aktif karena mereka lebih banyak bertanya.

Dengan melihat hasil refleksi pada siklus I di atas, maka guru/peliti harus melakukan tindakan perbaikan di siklus II. Tindakan tersebut atara lain: (1) memaksimalkan pelaksanaan Problem Based Learning dengan mengikuti semua sintaksnya sehingga siswa benar-benar memahami apa yang harus mereka lakukan dalam proses pembelajaran, (2) guru/peneliti memberikan perhatian yang lebih kepada semua siswa sehingga mereka semua menjadi lebih aktif mengikuti pembelajaran, (3) lebih memerhatikan pembentukan kelompok dengan harapan bahwa siswa yang berkemampuan lebih dapat membimbing temannya jika mengalami kesulitan, dan (4) untuk meningkatkan kemampuan kognitif, maka guru/peneliti mempersiapkan materi yang harus dipelajari oleh setiap peserta didik dan akan diujikan lewat pre-test dan post-test.

\section{Siklus II}

Fase perencanaan dan pelaksanaan tindakan pada siklus II sama dengan yang telah dilakukan pada siklus I. Bedanya hanya pada siklus II diadakan perbaikan-perbaikan sebagaimana solusi yang direncanakan pada fase refleksi siklus I. Penguasaan kelas yang dilakukan oleh guru/peneliti sudah lebih baik sehingga sebagian besar siswa bisa melaksanakan setiap tahapan dalam model pembelajaran Problem Based Learning dengan baik. Selain itu bisa terlihat juga bahwa hampir seluruh siswa merasa antusias mengikuti pembelajaran sehingga kelas terasa lebih hidup dalam suasana yang kondusif. Sedangkan hasil pengamatan dan tes selama proses pembelajaran pada Siklus II dapat dilihat pada grafik di bawah ini.

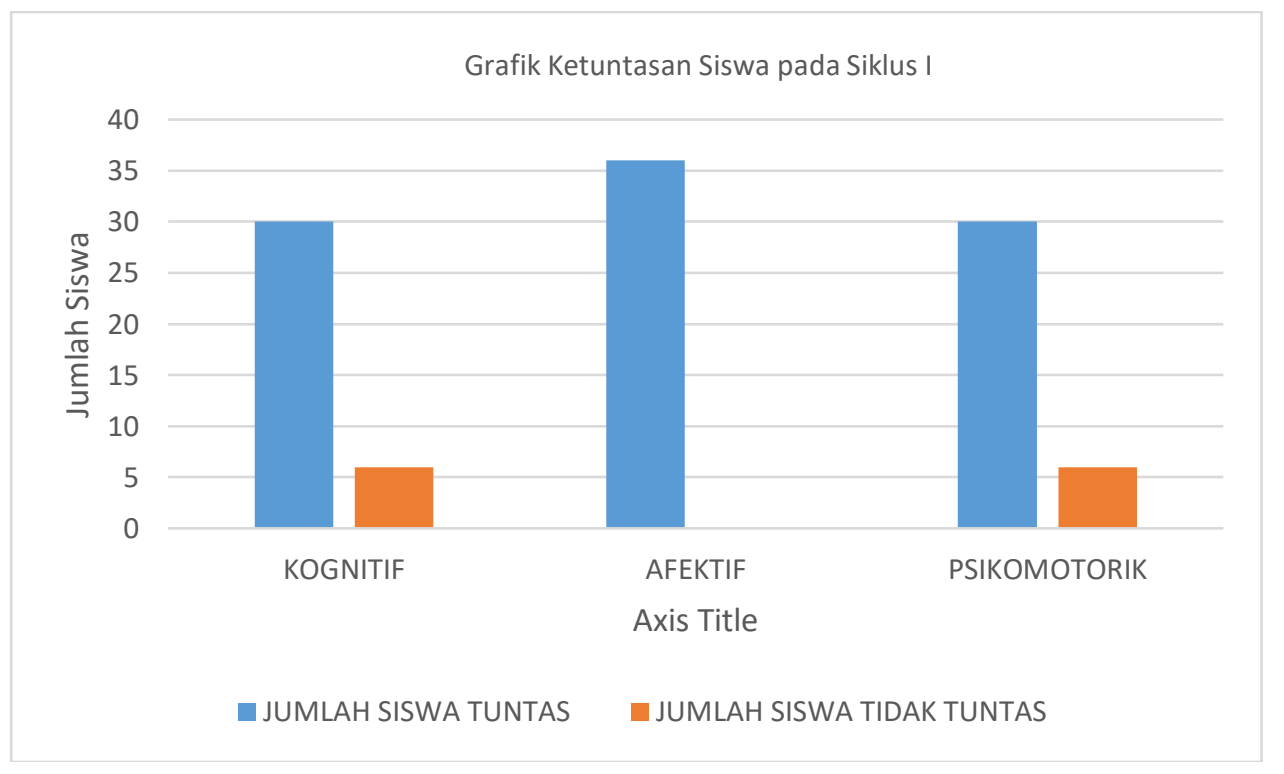

Gambar 2. Hasil Pengamatan Siklus 2 
Grafik di atas menunjukkan bahwa hasil belajar Passive Voice siswa XI OTKP 2 pada Siklus II mengalami kemajuan yang baik. 30 siswa telah tuntas untuk ranah kognitif, semua siswa untuk afektif, dan 30 siswa untuk psikomotorik. Grafik tersebut juga menunjukkan bahwa ketuntasan klasikal kelas XI OTKP 2 dalam mempelajari Passive Voice sudah tercapai karena sudah mencapai $89 \%$.

Keberhasilan guru/peneliti dalam menerapkan Problem Based Learning juga mengalami peningkatan. Jika pada Siklus I keberhasilan guru/peneliti hanya 45\%, maka pada Siklus II meningkat menjadi 92\%. Hal ini juga disebabkan oleh karena guru/peneiliti memperbaiki tindakan-tindakan sesuai dengan solusi yang ditetapkan pada fase refleksi Siklus I.

\section{B. Pembahasan}

Hinkel (2002) dalam Halik \& Kareema (2020), menyatakan bahwa banyak guru Bahasa Inggris sebagai bahasa kedua maupun bahasa asing menyadari dari pengalaman mengajar masing-masing bahwa mengajarkan arti, penggunaan, dan fungsi Passive Voice merupakan salah satu masalah signifikan. Hal ini juga dialami oleh guru/peneliti dalam mengajarkan materi ini. Pada Pembelajaran di siklus I, penguasaan siswa XII OTKP 2 sangat kurang karena mereka yang mencapai ketuntasan belajar belum mencapai $85 \%$ dari keseluruhan jumlah siswa -baik untuk aspek kognitif, afektif, maupun psikomotorik. Hal ini bisa dimungkinkan oleh karena keberhasilan guru/peneliti dalam menerapkan model pembelajarannya masih relatif rendah juga, yakni 45\%. Namun demikian ada beberapa permasalahan dari siswa sendiri yang membuat model Problem Based Learning yang diterapkan belum berhasil maksimal. Salah satu diantaranya adalah kurangnya keseriusan mereka dalam mengikuti pembelajaran.

Sebagaimana dinyatakan oleh Halik dan Kareema (2020) bahwa pembelajaran grammar -termasuk Passive Voice- akan lebih mudah disampaikan dan diterima siswa ketika mengintegrasikannya dalam pembelajaran ketrampilan berbahasa seperti Listening, Speaking, Reading, dan Writing; maka guru/peneliti pun melanjutkannya dalam pembelajaran di siklus II pada pembelajaran Reading Skill. Hasil belajar mereka meningkat pada pembelajaran siklus II. Sebanyak 30 siswa dari total 36 siswa bisa menuntaskan pembelajaran merekan pada aspek kognitif dan psikomotorik. Sedangkan semua siswa sudah berhasil menuntaskannya pada aspek afektifnya. Hal ini bisa diartikan bahwa ketuntasan klasikal telah tercapai karena lebih dari 85\% siswa telah menuntaskan pembelajaran Passive Voice mereka dengan diterapkannya model Problem Based Learning.

Naiknya presentasi keberhasilan guru -sebesar 47\%-dalam menerapkan model Problem Based Learning juga memberikan andil yang positif. Salah satu alasan semakin bersemangatnya siswa untuk mengikuti pembelajaran adalah bahwa guru/peneliti semakin memperbaiki penerapan model pembelajaran yang telah dirancang. Dengan model ini, siswa benar-benar diberi kebebasan untuk mengeksplorasi kemampuan mereka untuk mencari dan mengolah data untuk menyelesaikan masalah yang diberikan. Kerjasama dengan kelompok dan diskusi antar kelompok juga sangat bagus. Hal ini selaras dengan yang telah dinyatakan Fauzan (2019) bahwa model pembelajaran ini dapat meningkatkan kemapuan bekerja kelompok, hubungan, dan interaksi antar siswa. Mereka bekerja sama dengan baik sehingga menghasilkan solusi terbaik yang bisa diterima oleh semua warga kelas. Akhirnya pengetahuan dan keterampilan barupun mereka peroleh dengan difasilitasi oleh guru/peneliti.

\section{KESIMPULAN}

Berdasarkan hasil penelitian dan pembahasan yang dikemukakan, maka dapat disimpulkan bahwa setelah guru/peneliti memberikan tindakan dengan menerapkan model pembelajaran Problem Based Learning pada siswa kelas XI OTKP 2 SMK Negeri 2 Blitar semester genap tahun pelajaran 2019/2020 terjadi perubahan keterampilan mereka dalam penggunaan Passive Voice. Perubahan tersebut bisa dilihat pada hasil observasi maupun posttest yang telah dilakukan pada tindakan di siklus I dan siklus II. Perkembangan hasil belajar 
diambil pada aspek kognitif, afektif, dan psikomotorik. Selanjutnya perkembangan yang baik ini menunjukkan bahwa Reading Skill siswa terkait dengan Passive Voice juga mengalami peningkatan dari $33 \%$ menjadi $83 \%$. Hal ini menunjukkan juga bahwa ketuntasan belajar mengalami peningkatan dari $33 \%$ menjadi $89 \%$. Akhirnya dengan adanya peningkatan yag baik ini, guru/peneliti/penulis merekomendasikan rekan-rekan guru Bahasa Inggris yang lain untuk mencoba menerapkan model Problem Based Learning untuk membelajaran di kelas untuk materi yang sama maupun berbeda.

\section{DAFTAR PUSTAKA}

Arikunto, Suharsimi, 2002. Prosedur Penelitian. Jakarta: PT Rineke Cipta.

Fathurrohman, Muhammad. (2015). Model-Model Pembelajaran Inovatif. Jogjakarta: Ar-Ruzz Media.

Fauzan, M., Saleh, N.T., \& Prabowo, A. (2019) Penerapan Pembelajaran Model PBL dengan Metode Tutor Sebaya pada Materi Statistika untuk Meningkatkan Ketuntasan Klasikal Siswa Kelas XII MIPA 1 SMAN 9 Semarang Tahun Pelajaran 2018/2019. PRISMA, Prosiding Seminar Nasional Matematika 2, 403-409 from https://journal.unnes.ac.id/sju/index.php/prisma/article/view/28963/12669

Halik, A.F.A. \& Kareema, M.I.F. (2020). Difficulties faced by the ESL Learners in using English Passive Voice in Written Communication: A study base don the Students of NAITA, Trincomalee, Sri Lanka. KALAM - International Research Journal Faculty of Arts and Culture, South Eastern University of Sri Lanka. I3(3), from http://ir.lib.seu.ac.lk/bitstream/handle/123456789/5285/05.\%20K2020\%20$\% 20 \% 2851-59 \% 29$. pdf? sequence $=1 \&$ isAllowed $=\mathrm{y}$

Ruzhekova-Rogozherova, Boryana. (2012). Teaching English Passive Cotrastively and in Comparison with other Categories. from

https://www.researchgate.net/publication/312951343_TEACHING_ENGLISH_PAS SIVE_CONTRASTIVELY_AND_IN_COMPARISON_WITH_OTHER_CATEGO $\underline{\text { RIES }}$

Tomlinson, Brian. (2008). English Language Learning Material. London: Continuum International Publishing Group. 